\title{
Protecting Your InTEllectual Capital IN THE CANADIAN OIL AND GAS INDUSTRY
}

\author{
FRANK TOSTO AND EVAN NUTTALL*
}

Technological advancements are a key economic driver in the energy sector, particularly in the Alberta oil sands. Underlying the commercialization and use of such advancements are patents, trade secrets, and other intellectual property assets that can provide a competitive advantage in the energy sector. Appropriate planning and processes help maximize the advantage and minimize the risks associated with developing, protecting, licencing, enforcing, and otherwise leveraging intellectual property in the energy sector. This article includes a brief description of patents and trade secrets under Canadian intellectual property law. The article also includes a review of issues related to protecting patents and trade secrets, both in terms of developing the assets themselves and in terms of ensuring clarity of ownership with respect to employment and other contractual relationships between inventors and owners, as well as assignees, particularly within the context of joint ventures. Finally, the article provides a review of current Canadian law relevant to the enforcement of patents, with a focus on issues likely to arise in the litigation of patents for technology and trade secrets used in the oil and gas industry.
Les progrès technologiques représentent un moteur économique clé du secteur de l'énergie, surtout dans les sables bitumineux de l'Alberta. À la base de la commercialisation et de l'utilisation de ces progrès se trouvent les brevets, les secrets commerciaux et autres actifs de propriété intellectuelle pouvant constituer un avantage concurrentiel dans ce secteur. Une planification et des méthodes appropriées aident à maximaliser l'avantage et à réduire les risques associés au développement, à la protection, à l'émission et au respect des permis et aux autres éléments permettant de profiter de la propriété intellectuelle dans le secteur énergétique. Cet article comprend une courte description des brevets et des secrets commerciaux existants en vertu de la loi canadienne sur la propriété intellectuelle. L'article comprend aussi un examen des questions relatives à la protection des brevets et des secrets commerciaux, à la fois sur le plan de l'élaboration des actifs en soi et sur le plan de la transparence de la propriété en ce qui concerne les relations d'emploi et les autres relations contractuelles entre les inventeurs et les propriétaires ainsi que les cessionnaires, surtout dans le contexte de coentreprises. Enfin, l'article donne une idée de la loi canadienne en vigueur sur le respect des brevets, avec une attention spéciale aux questions pouvant vraisemblablement surgir dans les litiges sur les brevets de technologies et les secrets commerciaux utilisés dans le secteur gazier et pétrolier.

\section{TABLE OF CONTENTS}

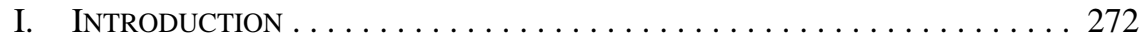

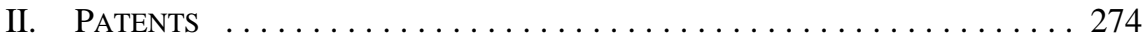

III. TRAdE SeCRETS . . . . . . . . . . . . . . . . . . . . . . . . 274

IV. Protecting InVEntions Through Patents $\ldots \ldots \ldots \ldots \ldots \ldots \ldots 275$

A. InVENTORSHIP . . . . . . . . . . . . . . . . . . . . . . 276

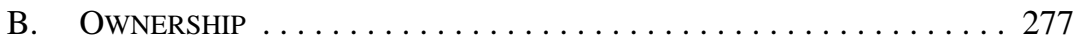

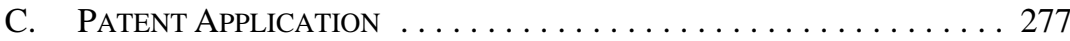

D. Practical Issues . . . . . . . . . . . . . . . . . . . . . . . . . . 278

E. Issued PATENT . . . . . . . . . . . . . . . . . . . . . 279

V. Protecting Technology as a Trade Secret . . . . . . . . . . . 279

VI. Protecting InTELlectual PRoperty in Joint Ventures . . . . . . . . . 281

Frank Tosto is a partner in the Calgary office of Borden Ladner Gervais and is the regional leader of the Intellectual Property Litigation Group. Evan Nuttall is also a partner in the Calgary office of Borden Ladner Gervais. The authors would like to thank David Wood, Landon Miller, Tim Webb, Duncan Marsden, and LuAnne Morrow. 
VII. Protecting Intellectual Property — Employment LaW . . . . . . 282
A. DURING EMPLOYMENT -
THE Duty of FidELITY/GOOd FAITH $\ldots \ldots \ldots \ldots \ldots \ldots$

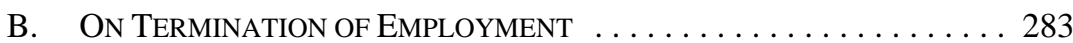

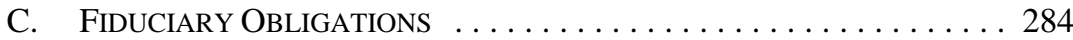

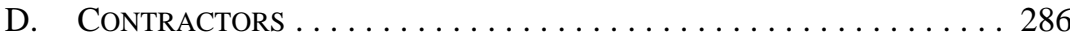

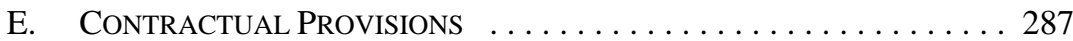
F. PRACTICAL ISSUES . . . . . . . . . . . . . . . . . . 288

VIII. ENFORCEMENT OF PATENTS . . . . . . . . . . . . . . . . . . . . . . . . . . 289

A. INFRINGEMENT AND IMPEACHMENT ACTIONS . . . . . . . . . 290

B. Construction ........................ 291

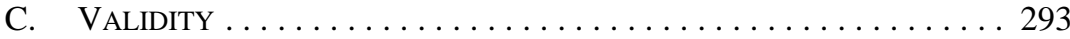

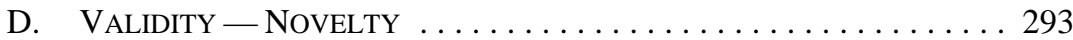

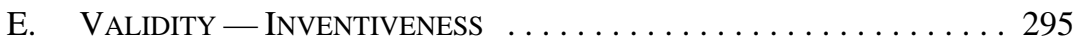

F. VALIDITY - SOUND PREDICTION OF UTILITY, DEMONSTRATION OF UTILITY, AND PROMise of THE PATENT . . . . 297

G. VALIDITY - SECTION $53(1) \ldots \ldots \ldots \ldots \ldots \ldots \ldots \ldots \ldots \ldots \ldots$

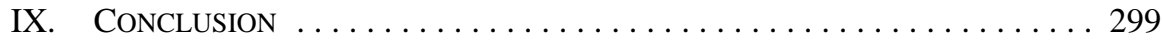

\section{INTRODUCTION}

Alberta's oil sands underlie approximately 140,200 square kilometres $\left(\mathrm{km}^{2}\right)$ of land in the Athabasca, Cold Lake, and Peace River areas in northern Alberta. Together, these oil sands areas contain an estimated 1.8 trillion barrels (initial volume in place) of crude bitumen. However, only "[a]bout $10 \%$ of this volume (169.3 billion barrels) is recoverable using current technology." " Despite the vast majority of crude bitumen being currently inaccessible, the oil sands industry is showing no signs of slowing down. From 2000 to 2009, oil sands production doubled from 0.6 million barrels per day (mbd) to $1.35 \mathrm{mbd}^{2}$ By 2020 , it is expected that "oil sands output is likely to double again and could be higher than the national production from several OPEC member states.”3

Steam-assisted gravity drainage (SAGD) and cyclical steam stimulation technologies have transformed the oil sands industry, allowing previously unrecoverable bitumen to be extracted. As approximately 80 percent of recoverable oil sands deposits are too deep for surface mining, innovations in technology have been required for their recovery. ${ }^{4}$ By some estimates, production from SAGD processes currently makes up 18 percent of oil sands production and, with advances in technology, this percentage is expected to increase to more than 40 percent of the total production by $2030 .^{5}$ As producing formations become depleted and new wells are drilled in increasingly less favourable formations, advances in technology may provide greater total recovery, efficiency, and cost-effectiveness. Increasingly stringent energy.alberta.ca/oilsands/791.asp>.

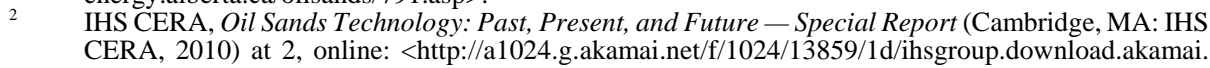
com/13859/ihs/cera/Oil-Sands-Technology-Past-Present-and-Future.pdf $>$.

Ibid.

Ibid at 3.

Ibid at 7. 
environmental regulations restricting greenhouse gas (GHG) emissions and the use of fresh water in the recovery of oil sands deposits provide further incentive for improving current technology.

Several advances designed to increase energy efficiency, decrease water consumption, and decrease GHG emissions have already been made. For example, in situ combustion technologies use combustion within reservoirs to increase the viscosity of bitumen, which increases the mobility of the bitumen and allows for the extraction of a partially upgraded product. ${ }^{6}$ Similarly, hybrid solvent extraction and electric heating methods have allowed extraction to take place in low heat, low energy environments that require no water for production. $^{7}$

While these innovations help the oil sands industry tap into increasingly more difficult to access bitumen reserves, it is clear that further innovation is required to explore reserves that cannot be accessed with current mining and in situ technologies. For example, approximately "410 billion barrels of bitumen-in-place [are] found in sand deposits that are too thin for economic SAGD production," ${ }^{8}$ resulting in costly heat loss to other adjacent formations. As well, approximately 477 billion barrels of bitumen-in-place are locked in carbonate rocks or limestone, which contain discontinuities and fractures that make steam containment within a particular chamber difficult. ${ }^{9}$

As innovation continues to be a driving force behind oil sands production in Alberta, intellectual property that stems from research and the development of new technology should be protected and licenced, enforced, or otherwise leveraged to realize additional value and protect research and development investments. Canadian intellectual property law embodies technology in patents, trade secrets, and copyright. Through these legal constructs, technology, know-how, data, and software become assets that can be measured and leveraged beyond their utility as technology and data. As with most assets, maximizing the value of intellectual property requires planning and direction. Without a plan for how to best capture and protect intellectual property and a strategic plan for its development, protection, enforcement, and utilization, significant market value and competitive advantage may be lost.

This article is not intended to provide a comprehensive review of Canadian intellectual property law. Rather, it is intended to summarize relevant Canadian law on patents, trade secrets, and other confidential information, ${ }^{10}$ and to provide examples of how these intellectual property assets can be leveraged to benefit entities operating in energy industries, with a focus on recovery from oil sands formations.

Ibid at 26 .

Ibid at 27.

Ibid at 29.

Ibid.

Trademarks identify the source of goods to consumers and can be extremely valuable assets to protect goodwill and reputation. Copyright protects software and compilations of data. While trademarks and copyright may also be valuable assets in the energy sector, their generation and use are beyond the scope of this article. 


\section{Patents}

A patent is a public document that provides its owner with an entitlement to enforce a monopoly during a specified term. ${ }^{11}$ The Commissioner of Patents ${ }^{12}$ will grant a patent for an invention when certain requirements for the issuance of a patent are met. ${ }^{13} \mathrm{~A}$ patent must include a specification that "correctly and fully describe[s] the invention and its operation or use as contemplated by the inventor." 14 The specification must end with one or more "claims defining distinctly and in explicit terms the subject-matter of the invention for which an exclusive privilege or property is claimed." 15 A patent may be likened to a bargain between the Commissioner of Patents and an applicant for a patent. In this analogy, the monopoly, as defined in the claims, is the consideration provided to the applicant by the Commissioner of Patents. In exchange, the remainder of the specification is provided by the applicant and published, enriching public knowledge. ${ }^{16}$

The "description" is a portion of the specification describing the invention in written language. The description includes a title and a technical field, and also describes the background, the invention, figures (if any), and at least one mode of carrying out the invention. ${ }^{17}$ The subject matter of a "claim" must be novel, ${ }^{18}$ inventive,${ }^{19}$ and useful. Utility is a portion of the definition of "invention" in the Patent Act, which states that an invention includes "any new and useful art, process, machine, manufacture or composition of matter, or any new and useful improvement in any art, process, machine, manufacture or composition of matter." ${ }^{20}$ In the oil and gas context, examples of subject matter that are a process, a machine, and a manufacture or composition of matter are, respectively, a method of recovering bitumen, a downhole tool, and a drilling fluid.

\section{TRADE SECRETS}

Some inventions, depending on their nature, may simply be kept secret rather than being disclosed and claimed in a patent. In this case, the invention is embodied in a trade secret. Trade secrets that are legally protectable are those that are kept secret from the public. Trade secrets are contextual and difficult to precisely define. ${ }^{21}$ Broadly, trade secrets are forms of

Patent Act, RSC 1985, c P-4, ss 10, 32, 44, 54-59.

The Commissioner of Patents is appointed by the Governor in Council. The Commissioner exercises the powers and performs the duties specified in the Patent Act under the direction of the Minister of Industry. See Patent Act, ibid, s 4.

Ibid, s 27(1).

Ibid, s 27(3)(a). See sections 2(3)(b)-(d) for other requirements of the specification.

Ibid, s 27(4).

See e.g. Consolboard v MacMillan Bloedel (Sask) Ltd, [1981] 1 SCR 504 at 517 [Consolboard], where the Court provided that "[t]he description of the invention therein provided for is the quid pro quo for which the inventor is given a monopoly for a limited term of years on the invention."

Patent Rules, SOR/96-423, ss 80(a)-(f). Where the invention is a machine, the Patent Act, supra note 11 , s 27(3)(c) requires that the description explain "the best mode in which the inventor has contemplated the application of that principle." An abstract is also present in the patent, but unlike the specification, the abstract "cannot be taken into account for the purpose of interpreting the scope of protection sought or obtained” (see the Patent Rules, ibid, s 79(1)).

Patent Act, ibid, s 28.2 .

Ibid, s 28.3 .

Ibid, s 2 .

CPC International v Seaforth Creamery (1996), 69 CPR (3d) 297 at para 22 (Ont Ct J (Gen Div)) [CPC International]. 
information that are not generally publicly known and which give the owner of the secret a competitive or economic advantage over others who are unaware of the information. ${ }^{22}$

Trade secrets are not expressly protected or enforceable by statute in Canada. However, trade secrets are "a particular kind of confidential information." ${ }^{23}$ As a result, disclosure or other misuse of a trade secret will support an action for breach of confidence in a provincial superior court. The same legal tests apply to a breach of confidence in relation to either trade secrets or confidential information. ${ }^{24}$ The Supreme Court of Canada has created a three-part test for a successful breach of confidence claim where confidential information has been used: "First, the information itself ... must 'have the necessary quality of confidence about it.' Secondly, that information must have been imparted in circumstances importing an obligation of confidence. Thirdly, there must be an unauthorized use of that information to the detriment of the party communicating it." ${ }^{~} 5$ It is generally under the first branch of the LAC Minerals test that a court will consider whether a particular piece of information is “confidential.” In Cadbury Schweppes, the Supreme Court of Canada held that "[e]quity has set a relatively low threshold" ${ }^{26}$ to the kinds of information that will have the necessary quality of confidence about it and that " "some product of the human brain' applied to existing knowledge might suffice."27

Breach of confidence claims have been successful in respect of a variety of types of confidential information: pressure data for a gas well, ${ }^{28}$ geological data, ${ }^{29}$ environmental assessments ordered by parties to a negotiation, ${ }^{30}$ offers, ${ }^{31}$ and customer lists with rates. ${ }^{32}$ The proceeding discussion of trade secrets is based on breach of confidence cases relating to trade secrets and/or to other confidential information.

\section{Protecting InVentions Through Patents}

Successfully building a patent portfolio in any technical field requires direction and a well-defined process. Direction is determined by the business goal sought to be achieved by protecting a given technology. Process becomes more important as the portfolio increases in depth and breadth. Directing the growth of the portfolio and preparing the process used to do so requires the professional skills of patent agents and lawyers, and the managerial

John S Macera \& Amy M Thomas, “Trade-secrets and Confidential Information” in Ronald E Dimcock, ed, Intellectual Property Disputes: Resolutions and Remedies, loose-leaf (consulted on 14 October 2012), (Toronto: Carswell, 2002) ch 5 at 1 [Intellectual Property Disputes]. See also Cinabar Enterprises Ltd v Richland Petroleum Corp, 1998 ABQB 653, 225 AR 161 at paras 54-55 [Cinabar]. $R v$ Stewart, [1988] 1 SCR 963 at 975, cited in Cadbury Schweppes v FBI Foods Ltd, [1999] 1 SCR 142 at para 40 [Cadbury Schweppes].

Cadbury Schweppes, ibid at paras 66, 94, 97.

LAC Minerals Ltd v International Corona Resources Ltd, [1989] 2 SCR 574 at 635-36 [LAC Minerals], citing Coco v AN Clark (Engineers) Ltd, [1969] RPC 41 (Ch) at 47 [Coco].

Supra note 23 at para 75.

Ibid, citing Coco, supra note 25 at 47.

Murphy Oil Co v Predator Corp, 2006 ABQB 680, 408 AR 98 at paras 5, 183 [Predator].

Lac Minerals, supra note 25.

Abode Properties Ltd v Schickedanz Bros Ltd, 1999 ABQB 902, 254 AR 91 at para 41.

Ibid at para 42.

Monarch Messenger Services Ltd v Houlding (1984), 56 AR 147 (QB) at para 14. See also Provincial Plating Ltd v Steinkey, [1998] 3 WWR 1 (SKQB) at para 17 with respect to duties of non-fiduciary employees. See contra Imperial Sheet Metal Ltd v Landry, 2007 NBCA 51, 315 NBR (2d) 328 at paras 40-42 [Imperial Sheet Metal], where it was held that customer lists could not be confidential information. 
skills of the entity building the portfolio. As discussed above, the subject matter claimed in a patent must be novel, inventive, and useful. The process must, therefore, facilitate the filing of patent applications directed to novel, inventive, and useful subject matter. To a large extent, this means two things. First, a given patentable feature of an invention must be kept secret until a patent application that discloses and claims the feature is filed. Second, the utility of any features of an invention that will be claimed in a patent application must be described in the application and the description must support the subject matter of the claims.

In order to be granted a patent in Canada, an applicant must file a patent application with the Canadian Intellectual Property Office (CIPO). All patent applications have a filing date and one or more claim dates. Protection in other countries requires filing patent applications with their CIPO equivalents. ${ }^{33}$ The filing date may be the date on which the necessary documents and fees are received at CIPO. ${ }^{34}$ In the case of a Patent Cooperation Treaty ${ }^{35}$ application entering national phase in Canada, ${ }^{36}$ the filing date is the date accorded to the PCT application by a receiving office. ${ }^{37}$

\section{A. INVENTORSHIP}

The inventor owns a patent by default. Where more than one inventor is listed, each inventor holds an equal share in the patent. An inventor may assign a portion or all of their interest in a patent. The assignment must be in writing and must be registered with CIPO to be valid against subsequent assignees. ${ }^{38}$ Employees' obligations to assign a patent in the context of a conventional employment situation, a joint venture, and a consulting scenario are discussed later in this article.

In part because ownership flows from inventorship, and due to issues pertaining to enforcement (which will be discussed below), incorrectly naming inventors in a patent application may result in an issued patent becoming void, and may add another issue to litigation and increase costs and uncertainty. Accordingly, it is important to name the correct individuals as inventors on a patent application. Inventors are the individuals who contributed to the conception and reduction to practice of the claimed invention. ${ }^{39}$

For example, the United States Patent and Trademark Office, the State Intellectual Property Office (China), and the European Patent Office. A patent granted by the European Patent Office must be validated in each individual European country where the patent holder wishes to enforce it.

Patent Act, supra note 11, s 28(1).

19 June 1970, 1160 UNTS 231, 9 ILM 978 (entered into force 24 January 1978) [PCT].

Canada is a party to the PCT. As a result, a patent application pursuant to the PCT may form the basis of a Canadian application. Most countries are PCT members, with two notable exceptions (for the purpose of this article) being Venezuela and Saudi Arabia. A PCT application may be filed with either a receiving office in a country where the applicant has residence or nationality, or with the international bureau in Geneva (Regulations under the Patent Cooperation Treaty, entered into force 1 July 2011, r 19.1(a)). The PCT application may "enter national phase" in Canada, that is, become a patent application pending at CIPO, and benefit from the filing date of the PCT application. PCT applications must enter national phase in Canada no later than 30 months from a priority date of the PCT application, or 42 months with payment of an additional fee. As will be discussed below, a priority date is analogous to a claim date, but applies to an entire application rather than to individual claims. See Patent Rules, supra note 17 , ss $50-66$.

Patent Rules, ibid, s 64(2).

Ibid, ss 49-51.

Inventorship will be discussed further below. Readers should refer to Part VIII.G. 


\section{B. OWNERSHIP}

Each inventor remains an inventor throughout the patent application process and following the granting of the patent. However, ownership of the invention may be transferred between parties by assignment of ownership. The owner of a patent is entitled to enforce and licence the patent. As discussed below, agreements (or the common law, in the absence of an express agreement) will direct which corporate entity will own the inventions of employees and contractors. Details of contractual terms specifying which entity or entities will own patents and safeguard trade secrets may be directed by consideration of which entity or entities will be using the technology and creating, protecting, enforcing, and licencing the patents and trade secrets.

\section{Patent Application}

Each claim in a patent application or patent has a claim date. The default claim date is the filing date of the application. A claim date may be earlier than the filing date where: (1) a patent application was previously filed in a foreign country; ${ }^{40}(2)$ the previously filed application discloses the subject matter of the claim; and (3) the Canadian application is filed within one year after the filing date of the previously-filed application. ${ }^{41}$ Thus, the claim date may be up to one year prior to the filing date. ${ }^{42}$

Some legal tests are applied as of the filing date of a patent application or as of the claim date of a claim. These legal tests include the tests for novelty, inventiveness, and utility. Unless an applicant requests early publication, patent applications publish 18 months after the earlier of the filing date or the earliest claim date. ${ }^{43}$

The subject matter of a claim must be novel. That is, the subject matter must not have been disclosed to the public by a person other than the applicant (or a person who obtained knowledge of the invention from the applicant) in a manner which caused the invention to become available to the public anywhere in the world before the claim date. ${ }^{44}$ Similarly, the subject matter of a claim must be inventive. Subject matter is inventive where it is not obvious to a person skilled in the art to which the claim pertains, having regard to information disclosed to the public prior to the claim date. ${ }^{45}$ In most jurisdictions, disclosure of subject matter by an applicant prior to filing a patent application is citable against the

40 At least one of the applicants must be a resident or citizen of a country that is a signatory to the Paris Convention for the Protection of Industrial Property, 20 March 1883, 828 UNTS 305, 21 UST 1583 (as revised 14 July 1967 and amended 28 September 1979); North American Free Trade Agreement Between the Government of Canada, the Government of Mexico and the Government of the United States, 17 December 1992, Can TS 1994 No 2, 32 ILM 289 (entered into force 1 January 1994) and a member of the World Trade Organization.

$41 \quad$ Patent Act, supra note 11, ss 28.1(1)(a)-(c). Section 28.1(2) requires the applicant to expressly request priority on the basis of the previously filed application. The foreign country does not have to be a member of the PCT.

42 An applicant may request priority on the basis of multiple previously filed applications in respect of a single Canadian application, provided that the above conditions are met for each previously filed application. Claims in a Canadian application may have different claim dates from each other, depending on which previously filed application discloses the subject matter of a given claim.

$43 \quad$ Patent Act, supra note 11, s 10.

Ibid, s 28.2(1)(b).

Ibid, s 28.3(b). The differences between novelty and inventiveness are discussed below at note 135 and accompanying text. 
application to prevent the claims from being either novel or inventive, and will preclude a valid claim to the disclosed subject matter regardless of how much time has elapsed between disclosure and filing. In Canada, disclosure by the applicant that occurs less than one year prior to the filing date that is not citable for either novelty or inventiveness will not preclude claiming the subject matter from being granted. ${ }^{46}$

\section{Practical IsSUES}

In an ideal world, a new invention could be created, refined, and perfected all in secrecy, before a patent application is made for the new invention. However, in the case of technology for use in an oil sands reservoir that requires regulatory approval, the disclosure of certain information to the regulator may be required to secure the necessary regulatory approval. This disclosure obligation may be in conflict with the need to keep the technical information confidential in order to maintain the novelty of the invention to seek patent protection. The Energy Resources Conservation Board Rules of Practice ${ }^{47}$ indicate that all documents filed in respect of a proceeding must be placed on the public record. To the extent that a party wishes to keep information confidential, a request must be made before filing. The Oil Sands Conservation Regulation ${ }^{48}$ states that the Energy Resources Conservation Board (ERCB) could accept certain information pertaining to an oil sands application as confidential where the information is "submitted to and accepted by the Board as confidential."49 Confidential treatment is not automatic under the OSCR and is subject to the test of whether disclosure is in the public interest. ${ }^{50}$

Under section 15(2) of the OSCR, “operations reports, special studies, laboratory, experimental or cost information relating to an oil sands commercial or experimental scheme concerning the development or application of a new or existing technology or improved operations" submitted and accepted by the ERCB as confidential will remain confidential for ten years, unless otherwise ordered by the Board. Section 15(3)(c) of the OSCR states that information referred to in section 15(2) may be made available to the public "if the person by whom it was submitted consents in writing to the release of the information.”

The ERCB's stated policy position in Informational Letter IL 92-11, which remains in effect, is that "[e]xperimental schemes involving novel design considerations or operating techniques may lead to the development of information of special proprietary value." ${ }^{\text {"T1 }}$ The ERCB further states that this type of information "need not be made part of an application."52 The policy statement in IL 92-11 creates an expectation that design considerations or operating techniques can be kept confidential by a proponent or a developer. In addition, an

Ibid, ss 28.2(1)(a), 28.3(a). The United States, Australia, and Mexico have a similar grace period.

Alta Reg 98/2011, s 13.

Alta Reg 76/88 [OSCR].

Ibid, s 15(2).

Alberta Energy and Utilities Board (EUB), EnCana Corporation: Review of Requirement to File Thermocouple Data Established in Decision 2003-023, Chard Area and Leismer Field (10 May 2005), Decision 2005-042, online: ERCB <http://www.ercb.ca/decisions/2005/2005-042.pdf>. 1992) at 2, online: ERCB <http://www.ercb.ca/ils/pdf/il92-11.pdf> [IL 92-11].

Ibid. 
operator of an in situ oil sands scheme is required to present regular performance reviews to the ERCB, which may include technically sensitive data. ${ }^{53}$

Given the relatively entrenched requirement to disclose such details, it is critical to either file for a patent application within one year of the earliest possible disclosure date, ${ }^{54}$ or to be extremely diligent in seeking and obtaining confidentiality from the ERCB and any other regulatory bodies.

\section{E. IsSUEd PATENT}

If a patent application complies with the Patent Act and Patent Rules, which encompass both formal requirements and substantive requirements (in other words, the claimed subject matter must be novel, inventive, and useful as discussed above), then CIPO will allow the patent application and, once the applicant pays a final fee, the patent will issue.

At this point, the owner has the exclusive right to "prevent others from depriving the [owner], even in part and even indirectly, of the monopoly that the law intends to be theirs: only the [owner] is entitled, by virtue of the patent and as a matter of law, to the full enjoyment of the monopoly conferred" ${ }^{\text {"55 }}$ for a term of 20 years from its filing date. ${ }^{56}$ It is commonly misunderstood that a patent provides the positive right to practise the invention it claims. Rather, a patent provides the right to enjoin, or to be compensated for, use of the subject matter of a claim by others. ${ }^{57}$

\section{Protecting Technology as a Trade Secret}

The value of a trade secret arises solely from the fact that it is a secret. If the confidentiality of a trade secret is not preserved by its holder, it will be lost and no protection will be afforded against its misuse or disclosure.

There are several reasons to rely on secrecy for the protection of technology rather than filing a patent application claiming the technology. These reasons include:

(1) An invention or idea is not patentable;

(2) Before a patent application is filed for an invention, the inventor may want to disclose it to a prospective user, purchaser, or financial backer;

53 Operators of in situ oil sands schemes are required to present regular performance reviews to the ERCB. Typically primary schemes must be presented triennially and commercial schemes annually. Resource Management Reports are required from some operators and, if non-confidential, are provided either as a separate submission or are incorporated into the performance presentations. Presentations on experimental schemes whose confidentiality periods have expired are also available, online: ERCB $<$ http://www.ercb.ca/data-and-publications/activity-and-data>.

54 Prior to the earliest possible disclosure if patent protection is to be sought outside of Canada, the United States, Mexico, or Australia. See the discussion on grace periods above, supra notes 43-45.

Monsanto Canada v Schmeiser, 2004 SCC 34, [2004] 1 SCR 902 at para 43 [emphasis in original]. Patent Act, supra note 11, s 44.

See ibid, s 32, with respect to a patent that improves on the subject matter of an existing patent. In this case, a licence to use the existing patent is required to use the improvement patent. 
(3) A belief in an anti-patent bias or trend of the courts; and

(4) The possessor may prefer secrecy over the expense of patent litigation, particularly if the patent is of doubtful validity. ${ }^{58}$

When a trade secret is vigorously protected, the information is more likely to remain secret. In addition, if there is a breach of confidence, a court is more likely to find that the information had the necessary quality of confidence and was communicated in confidence. Case law provides examples of such efforts to preserve secrecy. Implementation of administrative, technical, and physical safeguards to restrict access to and prevent unauthorized access of the information, such as security codes and passwords, or physical barriers, may be effective. ${ }^{59}$ Communication on a "need to know" basis is also good practice to preserve secrecy. ${ }^{60}$

A confidentiality or non-disclosure agreement (NDA) should be used at all times when it is necessary to communicate trade secrets to another party. The existence of an NDA informs the nature of the obligations and the reasonable expectations of the parties. ${ }^{61}$ Conversely, the lack of an NDA may increase the likelihood that a court would find that the information at issue did not have the necessary quality of confidence about it. ${ }^{62}$ In addition to NDAs, the existence of restrictive licences or employment agreements, which are clearly designed to protect the confidentiality of trade secrets, are strong evidence that the owner intended to keep the information secret.

A trade secret will be lost if it becomes generally known to members of the public, either through the public's independent endeavours or through disclosure by the owner of the trade secret. ${ }^{63}$ Information need not be known by the whole world in order to be considered public and, hence, no longer confidential. Information will be considered public if the community in which the information would have any significance is aware of it, even if that community is small. ${ }^{64}$ It is possible that applying skill and ingenuity to materials and resources that are available to the public may create something new and confidential; however, the end product must not be generally known to the public. ${ }^{65}$

Disclosure to the public of limited information relating to a trade secret does not necessarily result in a complete loss of the trade secret. The disclosure to the public must be to such a degree as to make it possible for a person to discover and duplicate the trade secret,

Robert A Choate, William H Francis \& Robert C Collins, Patent Law, 3d ed (St Paul: West Publishing, 1987) at 7.

Intellectual Property Disputes, supra note 22 at 5-64; Belform Insulation Ltd v Toleks Insulation Ltd (1998), 85 CPR (3d) 160 at para 6 [Belform]; Consolidated Textiles Ltd v Central Dynamics Ltd (1974), $18 \mathrm{CPR}(2 \mathrm{~d})$ at paras 40-41. As a further practical point, it may be prudent to ban cellular telephones with cameras and other cameras from a job site, lab, or other location where sensitive technology is being developed or applied.

Software Solutions Associates v Depow (1989), 99 NBR (2d) 110; CPC International, supra note 21 at para 27.

Aram Systems Ltd v NovAtel, 2008 ABQB 441, 449 AR 288 at para 108, aff'd 2009 ABCA 262, 457 AR 341, leave to appeal to SCC refused, 33351 (28 January 2010).

Cinabar, supra note 22 at para 56 . The tardiness of efforts to protect the information was also considered in the Court's finding that the information was confidential.

Macri v Miskiewicz, [1993] 8 WWR 46 (BCCA).

Ridgewood Resources Ltd v Henuset (1982), 35 AR 493 (CA) at para 27.

LAC Minerals, supra note 25 at 654. 
which will be contextual. In one example, the plaintiff allowed public tours and entry by delivery personnel to a manufacturing site. The plaintiff had also published limited information regarding its products in brochures. However, the plaintiff's actions had not compromised or disclosed the nature of its production process to such a degree as to permit anyone to duplicate it and, therefore, it remained a trade secret. ${ }^{66}$

In another example, down-hole pressure data from a wildcat well with "tight hole" regulatory status was confidential under the first branch of the Lac Minerals test. The pressure data was unknown and unascertainable to anyone other than the well owner and anyone to whom the owner was required to release the information. The fact the plaintiff had provided the public with limited information regarding flow rates and about the discoveries in the area did not cause the pressure data itself to become public. ${ }^{67}$

Where a product is used in public or sold without restriction, a trade secret embodied in the product may be lost. If the product can be reverse-engineered with ease, as is the case with many mechanical devices, then trade secrets in the product will likely be lost upon sale. ${ }^{68}$ In contrast, where reverse engineering is difficult, as may be the case with recipes for food, trade secrets are likely to be preserved despite unrestricted sales. ${ }^{69}$ Similarly, publication of a patent application disclosing an invention related to subject matter of a trade secret will not necessarily result in the loss of the trade secret. A product may include both patented features and features that are kept secret. Where a patent discloses the patented features but not the features that are kept secret, the trade secret is preserved. ${ }^{70}$ For example, a drill bit may be protected by a patent, while drilling fluid designed for it may be kept secret.

In the event of a limited breach of confidence, steps must be taken to preserve the secret in order to maintain the advantage afforded by a trade secret for the future. Typically, this means commencing an action and seeking injunctive relief to prevent the further dissemination of the confidential information, among other forms of relief. This step should be undertaken as soon as possible after discovering the breach of confidence. Other typical remedies include orders mandating the return or destruction of materials, damages, restitutionary awards, and the imposition of a constructive trust. ${ }^{71}$

\section{Protecting Intellectual Property in Joint Ventures}

Joint ventures are an increasingly common way for oil and gas companies to combine expertise and assets to accomplish a common goal by establishing a contractual relationship. This is particularly the case in Alberta oil sands projects, which are typically capitalintensive. ${ }^{72}$ Participants in joint ventures should not only pay special attention to how their

Belform, supra note 59 at para 10.

Predator, supra note 28 at para 58.

RI Crain Ltd v Ashton and Ashton Press Manufacturing Company Ltd, [1949] OR 303 at 7-8, aff'd (1949), [1950] OR 62 (CA).

CPC International, supra note 21.

Belform, supra note 59 at para 14.

LAC Minerals, supra note 25 at 579-80; Soulos v Korkontzilas, [1997] 2 SCR 217 at 243.

Aside from actual joint ventures between producers, 12 major producers have signed the generic Charter for Canada's Oil Sands Innovation Alliance (signed 1 March 2012, online: Canada's Oil Sands Innovation Alliance <http://www.cosia.ca/our-charter/charter/>). The Charter states: "While we remain competitors in all respects, we recognize that together we can deliver accelerated improvement in our environmental performance. We stand together to find solutions to the environmental challenges of oil 
constituent intellectual property is protected, but also to how intellectual property is developed and protected as a result of the joint venture.

The following best practices should be considered to avoid common pitfalls associated with joint ventures:

(1) A joint venture agreement should include appropriate intellectual property terms that address, at a minimum, intellectual property contributions, ownership, development, and protection.

(2) The joint venture parties should create an intellectual property management plan and designate an individual to ensure that intellectual property is being managed pursuant to the joint venture agreement.

(3) The joint venture parties should create a jointly-owned legal entity separate from the joint venture that will own any jointly-owned intellectual property. The separate entity can then licence the intellectual property to the joint venture participants and to third parties. The separate legal entity also creates a practical way to manage intellectual property, as well as to design royalty arrangements or profits from the intellectual property developed pursuant to the joint venture.

(4) As discussed further below, clarifying employee roles under the joint venture is key. By having clear job descriptions and implementing safeguards, such as separate office space for employees acting for the joint venture (as opposed to one of the joint venture parties), the odds of co-mingling intellectual property can be reduced.

\section{Protecting Intellectual Property - EMPLOYMENT LAW}

A fundamental plank in any entity's intellectual property strategy should be the thorough consideration of how workers will interact with the intellectual property. Employment and contractual protection are relevant where workers have access to intellectual property or are responsible for the implementation and safeguarding of the intellectual property.

Generally, there are two types of workers - employees and contractors - who each owe different types of obligations with respect to a corporation's intellectual property and confidential information. Those obligations may arise from the common law or under contract. As will be discussed further, the common law position differs substantially from what is industry practice through the use of contracts. Accordingly, special attention should be paid to contractual dealings with contractors, although contractual dealings with employees can be equally important.

sands development through innovation and collaborative action.” Concerning environmental challenges that are universally applicable to producers in the Alberta oil sands, these producers are joining forces as environmental innovators. 


\section{A. DuRING EMPlOYMENT - THE DUTY OF Fidelity/GOOD FAITH}

In instances where no confidentiality agreements exist in an employment contract, or if there is no employment contract at all, the courts may rely on the duty of honesty or good faith to one's employer (often called the duty of good faith). This requires employees to protect their employer's confidential information, particularly its trade secrets. The duty of good faith will apply to all employees (not just senior employees) ${ }^{73}$ so long as the employment relationship is still in effect. ${ }^{74}$ After the employment relationship terminates, the duty of fidelity/good faith will no longer apply.

The duty of good faith generally encompasses three elements:

(1) A duty of non-competition;

(2) A duty of confidentiality; and

(3) A duty to inform the employer of any relevant information learned or acquired during the period of employment.

During the term of employment, the duty of good faith prohibits an employee from engaging in work, either during his or her employment or in his or her spare time, that places the employer's confidential information at risk. Such obligations are enforced strictly by the court.

If there is evidence that the employee began using the employer's confidential information or trade secrets during his or her employment for his or her own benefit, then the employer may proceed against the employee on the basis of a breach of the implied duty of good faith. This can occur even if there are no contractual provisions binding the employee. Even during a period of working notice, an employee can be liable for improper use of the employer's confidential information. This is often when such behaviour occurs. ${ }^{75}$

\section{B. ON TERMINATION OF EMPLOYMENT}

On termination of the employment relationship, the former employee is also prohibited from using his or her past employer's confidential information by the common law duty of confidentiality. In the employment context, this common law duty requires employees not to divulge any information of their employer which is confidential and also requires them to take all reasonable steps to ensure that such information retains its confidential nature. An employee is free to take away in his or her mind the contents of any document and use this information, as long as it does not constitute a trade secret or confidential information. However, he or she cannot take a copy of it or deliberately memorize it. $^{76}$

$73 \quad$ See Imperial Sheet Metal, supra note 32 at para 33, where Justice Robertson ruled that non-fiduciary employees have "a duty not to disclose 'trade secrets' and other 'confidential information.””

See especially Globex Foreign Exchange Corp v Kelcher, 2011 ABCA 240, 513 AR 101 at para 25 [Globex].

See especially RBC Dominion Securities v Merrill Lynch Canada, 2008 SCC 54, [2008] 3 SCR 79 [RBC Dominion Securities].

See Faccenda Chicken Ltd v Fowler (1985), [1986] 1 All ER 617 (CA). 
An obvious problem for employers choosing to rely on the common law duty of confidentiality as a means of protecting its confidential information is that, in the absence of written agreements, there is no way of knowing with certainty what will be regarded by the courts as confidential. To assist in persuading courts that information is confidential, employers can take a number of practical steps. For example, in International Tools Ltd. v. Kollar, ${ }^{77}$ a manufacturing process was held to be entitled to protection as a trade secret, due in part to the security precautions taken by the parties involved. The process was carried out in a separate room to which access was closely controlled, manufacturing instructions were kept in that room at all times, and those employees working on the project were advised of its confidential character.

As in Kollar, employers can take practical steps to protect trade secrets and to increase the likelihood that a court would consider them to be confidential. Such steps include:

(1) Labelling information as confidential (a simple but remarkably effective and often overlooked procedure);

(2) Creating and circulating an office policy dealing with confidentiality that sets out what constitutes confidential information and how it might or should be protected;

(3) Giving specific warnings to employees about the secrecy of particular pieces of information and limiting and monitoring employee access to information. If these steps are taken by the employer, it is more likely that a court will impose obligations of confidentiality upon employees when judicial intervention is required.

\section{FIDUCIARY OBLIGATIONS}

A key employee may also owe fiduciary obligations to the employer. Fiduciaries owe additional common law duties to their employers, preventing such employees from revealing trade secrets or breaching confidentiality even in the absence of a written agreement. Generally speaking, if employees are found to be fiduciaries of their former employers, they breach their fiduciary obligations when they take confidential customer lists or use trade secrets of their former employers in a competing enterprise. ${ }^{78}$

In Frame v. Smith, ${ }^{79}$ the Supreme Court of Canada set out the following analysis with respect to fiduciary obligations:

Relationships in which a fiduciary obligation have been imposed seem to possess three general characteristics:

The fiduciary has scope for the exercise of some discretion or power.

[1966] 2 OR 201 (H Ct J), aff'd in part [1968] 1 OR 669 (CA) [Kollar].

Tree Savers International Ltd v Savoy, 1992 ABCA 34, 120 AR 368.

[1987] 2 SCR 99 [Frame]. 
(2) The fiduciary can unilaterally exercise that power or discretion so as to affect the beneficiary's legal or practical interests.

(3) The beneficiary is peculiarly vulnerable to or at the mercy of the fiduciary holding the discretion or power. $^{80}$

This analysis has been used repeatedly to find the existence of fiduciary obligations. ${ }^{81}$

The necessary elements for a key employee were set out in Imperial Sheet Metal, and include: (1) the employee being considered an integral and indispensable component of the management team; (2) the employee being involved in the decision-making process and; (3) the employee having broad access to confidential information. ${ }^{82}$ The difference between a key employee and a mere employee is the amount of responsibility designated to each. ${ }^{83} \mathrm{~A}$ mere employee only has a duty to protect trade secrets and customer lists, unless that duty is enlarged by contract. A key employee will hold a position of greater authority and will be subject to greater confidentiality obligations. However, not every key employee (or fiduciary) will be found to owe fiduciary obligations. That is a fact-specific determination to be decided on a case-by-case basis. ${ }^{84}$

In Anderson, Smyth \& Kelly Custom Brokers Ltd. v. Worldwide Customs Brokers Ltd., ${ }^{85}$ the Alberta Court of Appeal ruled that "[h]aving been vested with a high degree of trust and confidence, the indicia of a fiduciary relationship, a key employee is not then at liberty to betray the trust by soliciting the employer's clients for his own account or for someone else to his indirect benefit.” The same applies to trade secrets and confidential information. The Court held that the former employee had been an " 'integral part of the Plaintiff's Edmonton operation', and ... a 'key employee' ... [and, as such, was] accountable to the [former employer] on the basis of the higher fiduciary standard." 86

Courts have held that the bar for showing a prima facie case for breach of fiduciary duty is a fairly high one, due to the balancing of interests between the future livelihood of the employee and the future loss of profits to the employer. The Court in Imperial Sheet Metal made it clear that "if there is a clash between the interests of former employers in protecting their business interests and the interests of former employees in earning a livelihood, coupled with the public interest in free competition for goods and services, it is the interests of the former employee that generally prevail." ${ }^{87}$ Again, it is this attitude, taken by the courts, which makes relying on common law duties far less preferable to relying on specific contractual obligations.

81 See e.g. Easyhome Ltd v Casey, 2009 ABQB 735, 20 Alta LR (5th) 199. The Court found that the plaintiff had established a strong prima facie case that the defendant was a key employee and a fiduciary. The plaintiff had scope for the exercise of power in his position as Regional Manager and it was clear that he could exercise that power so as to affect the plaintiff's practical interests.

Supra note 32 at para 63.

Canadian Aero Service Ltd v O’Malley, [1974] SCR 592 at 606 [Canaero].

Flag Works v Sign Craft Digital (1978), 2007 ABQB 434, 427 AR 206 at para 31.

1996 ABCA 169, 184 AR 81 at para 24 [Worldwide].

Ibid at para 25.

Supra note 32 at para 37. 
The Supreme Court of Canada case of Canaero established a fiduciary relationship between employee and employer as one "which ... betokens loyalty, good faith and avoidance of a conflict of duty and self-interest." ${ }^{\prime 88}$ The relationship goes at least as far as the fiduciary employee not obtaining for himself any property or business advantage properly belonging to the corporation. Canaero has been cited to stand for the proposition that there is a clear distinction between those employees who are subject to (elevated) fiduciary duties and those who are not. Subsequent cases have served to further define that distinction. ${ }^{89}$

Where it can positively be established that an employee held a position of senior management or could be considered a key employee, he or she cannot exploit the vulnerability that arises from this unique relationship with his employer for his own business interests. ${ }^{90}$ The issue of vulnerability was addressed in GasTOPS Ltd. v. Forsyth. ${ }^{91}$ In that case, the Ontario Superior Court of Justice was focused on determining what constitutes taking advantage of a business opportunity in terms of a breach of fiduciary obligations owed to a former employer. The defendant employees in that case suggested that fiduciary duties in an employment relationship should only be imposed in cases where the employer experiences "extraordinary vulnerability" at the hands of the employee. ${ }^{92}$ The Court however, took Frame and other related decisions as authority for the beneficiary being "peculiarly" or "particularly" vulnerable at the hands of the fiduciary, given the uniqueness of the employment relationship. ${ }^{93}$ The employees in GasTOPS were found to be key employees. As a result of their responsibilities and the information they had access to, they owed a fiduciary duty to "provide reasonable notice of their intention to resign and not to misuse confidential information which was proprietary." ${ }^{94}$

The Court in GasTOPS went further to find that after an employee is identified as "key," determining whether an employee is a "fiduciary" is still a difficult endeavour. ${ }^{95}$ This involves an analysis of factors such as knowledge, discretion, trust, access to confidential information, relationship with customers, and vulnerability. ${ }^{96}$

\section{CONTRACTORS}

Even with express contractual documentation, it may be difficult to distinguish between an employee and a contractor. In addition, the courts have consistently held that the intention of the parties in this regard, while persuasive, is not determinative. ${ }^{97}$ The importance of distinguishing between the two is that it is highly unlikely that contractors will be bound by any of the common law employee obligations set out above. For this reason, among others, it is strongly recommended that corporate entities do not rely on common law obligations,

Supra note 83 at 606 .

See e.g. RBC Dominion Securities, supra note 75 at para 46, Abella J, dissenting in part.

Torcana Valve Services v Anderson, 2007 ABQB 356, 421 AR 157 at para 31, citing Physique Health Club Ltd v Carlsen (1996), 141 DLR (4th) 64 at 69 (Alta CA).

[2009] OJ no 3969 (Sup Ct J) (QL) [GasTOPS].

Ibid at para 155.

Ibid.

Ibid at para 156.

A fiduciary is described as one who is empowered to act on behalf of and for the benefit of another with the ability to affect that other's interest through the use of discretion.

GasTOPS, supra note 91 at paras 84-86.

671122 Ontario Ltd v Sagaz Industries Canada, 2001 SCC 59, [2001] 2 SCR 983 at paras 39-47. 
but enter into contractual provisions with both employees and contractors to help protect the corporate entities’ intellectual property.

\section{E. Contractual Provisions}

Written contractual intellectual property ownership and protection provisions are preferable to relying on common law obligations for a number of reasons:

(1) They can result in more certainty as to what constitutes a trade secret, as well as what is to be treated as confidential for other reasons;

(2) They can eliminate any doubt that the information is regarded by its owner as confidential and that it was given to the employee in confidence;

(3) By spelling out permitted uses, they can provide important guidance as to whether an employee or contractor's use of information constitutes unauthorized use; and

(4) They create a clear basis for legal action (breach of contract) and eliminate having to rely on the courts to select an implied basis for protecting the trade secret.

The position in Canada is that non-competition agreements (and other types of restrictive covenants) are, from an initial standpoint, void and unenforceable, as they are contrary to public policy in that they restrict an individual's freedom to choose whom he or she works or deals with. ${ }^{98}$ However, the courts in Canada appear willing to uphold such clauses if they are reasonable and go no further than is necessary to protect a legitimate business interest. The type of information which the employer is seeking to protect is key in the analysis of the enforceability of such clauses. ${ }^{99}$

"Reasonableness" of restrictive covenants requires the clauses to have geographic and temporal restraints, which are in pursuit of a legitimate objective and which are no broader than necessary to protect the interests of the employer. Clauses must also be clear and unambiguous. What is acceptable in any given case in terms of time, area, or scope of activity depends more than anything on the facts.

It is important to distinguish between trade secrets and an employee's personal knowledge, skill, and experience. No confidentiality agreement or other restrictive covenant can restrain or restrict an employee's use of personal knowledge or skills. In one Canadian case involving a departing employee, the court attempted to clarify the distinction as follows:

[The employee has] a right to use, for his own purposes after leaving the company's employ, personal knowledge acquired during his 21 years of work in this field while in the employ of the company, and it is evident that this knowledge would include a wide experience with the problems associated with the design and manufacture of boxcar heaters, including a knowledge of the sources of supply for materials and

$98 \quad$ Shafron $v$ KRG Insurance Brokers (Western), 2009 SCC 6, [2009] 1 SCR 157 at para 17.

$99 \quad$ Elsley Estate v JG Collins Insurance Agencies Ltd, [1978] 2 SCR 916. See also Herbert Morris Ltd v Saxelby, [1916-17] All ER Rep 305 (HL). 
component parts, and an approximate knowledge of the cost of constructing such heaters, the identity of the potential customers for same and for replacement parts, the names of the parties to deal with in these various companies and so forth. On the other hand, details of the design and specifications, including drawings and plans giving exact measurements arrived at by plaintiff after years of research and development in this field, part of which was done by [the defendant employee] personally, would constitute trade secrets or confidential information belonging to it and should not be taken, copied, or used by [the employee]. ${ }^{100}$

The comments above show that confidentiality agreements can restrict employees' use of confidential information that they themselves have generated, invented, or discovered. Frequently, employees are engaged in research, using an employer's resources and working under the guidance of the employer. Although the information being generated is not yet in existence at the time the agreement is entered into, it is clearly confidential in light of the nature of the relationship.

\section{F. Practical Issues}

Employers must remember that, when attempting to protect their trade secrets, they may need injunctive relief from a court. A court is unlikely to be persuaded that information is highly confidential and worthy of such protection if the employer has not taken basic practical steps to protect it themselves. Furthermore, in numerous recent cases, noncompetition agreements were held to be invalid owing to omissions, poor choice of wording, unfamiliarity with certain legal rules, or attempts to be over-inclusive. ${ }^{101}$

The courts often approach such agreements with a degree of scepticism, due to the belief that there is an inequality of bargaining power between the employer and the employee, which means that only the most reasonable clauses (which often provide limited protection) will be held to be enforceable. Covenants forbidding the disclosure of trade secrets generally tend to be reasonable. Other covenants that, if properly drafted, are likely to survive a legal challenge include:

(1) Restrictions on an employee's use of the trade secret beyond the use or application for which it is intended;

(2) Temporal limitations such as permitting the use of the trade secret only for a certain time and requiring that the use be discontinued after the termination of the agreement;

(3) Requirements that the employee return all confidential information — both original documents as well as any copies. This is difficult to police, however such a written agreement assures that an employee's failure to comply will give rise to a cause of action for breach of contract; and grounds dismissed, (1972), 8 CPR (2d) 15 (FCA), appeal on jurisdictional grounds allowed, (1976), [1977] 2 SCR 134. 
(4) Requirements that the employee return all company property (including laptops) on termination of employment. Such clauses can be invaluable in any injunction application, as they immediately demonstrate a breach of contract by the employee and potentially a nefarious intent.

Other issues that can be addressed in a confidentiality agreement include:

(1) Definitions of "confidential information" and "trade secrets";

(2) The permitted uses and disclosure of the information, both during the term of employment and afterwards;

(3) The obligations of confidentiality;

(4) Specific provisions for the return of all confidential information;

(5) Remedies for breaches;

(6) Provisions for post-termination secrecy; and

(7) Dispute resolution mechanisms.

In addition to confidentiality agreements, which present their own range of practical and legal issues, a number of other steps can be taken to protect the confidentiality of information made available to employees. Like most business decisions, providing an employee with access to secret information clearly has the potential to be worthwhile, yet there is also a downside risk. The risk may be minimized through the execution of agreements by incoming employees. The agreements should include terms by which the employees agree to assign to the employer all inventions and patent applications that were invented during the course of employment. It is also important that such agreements include a term that the employee will co-operate with the employer as necessary during the patent application process. Such agreements can be extremely valuable when employees are engaged in a research capacity where they enjoy considerable creative freedom. The lack of a clear agreement can lead to the employee owning an invention that the employer would have expected to own. ${ }^{102}$

\section{ENFORCEMENT OF PATENTS}

Aside from licencing revenues and attracting investment, the value of intellectual property portfolios can be maximized through enforcement of the asset's associated rights. Often, considerable time and expense are invested in obtaining a patent. Accordingly, it often makes sense to have the obtained monopolistic status enforced. In the context of the oil and gas industry and, specifically, the Alberta oil sands, monopolistic status concerning technology may provide a significant competitive advantage. 


\section{A. INFRINGEMENT AND IMPEACHMENT ACTIONS}

To enforce a patent, an action for patent infringement may be brought in either the Federal Court Trial Division or the provincial courts. ${ }^{103}$ Only the federal courts have the jurisdiction to grant an in rem remedy affecting the validity of one or more claims or of a patent as a whole. The vast majority of patent infringement actions in Canada are brought in the Federal Court Trial Division. Where there is a finding of infringement, ${ }^{104}$ a variety of remedies are available by orders of the court:

(1) An injunction preventing further infringement; ${ }^{105}$

(2) Payment of damages for infringement that ocurred after the grant of the patent; ${ }^{106}$

(3) Payment of reasonable compensation may also be ordered in respect of activity that occurred prior to issue of the patent, but following publication of the patent application, and that would have been an infringement had it occurred following issue of the patent; ${ }^{107}$

(4) Equitable relief, typically in the form of an accounting for profits; ${ }^{108}$ or

(5) A combination of some of the foregoing remedies (with the exception of accounting for profits and damages which are typically mutually exclusive, as described below).

The court has discretion as to whether a successful plaintiff in a patent infringement action is entitled to equitable relief. ${ }^{109}$ If the plaintiff is entitled to equitable relief, he or she must elect either equitable relief or damages; they are not entitled to both remedies. ${ }^{110}$ Many actions for patent infringement are bifurcated, as assessments of damages or profits are often complex and costly. ${ }^{111}$ The Patent Act includes a limitation period preventing remedies for acts of infringement that occurred more than six years prior to the commencement of an action. ${ }^{112}$ Liability for infringement may be ongoing. Where a defendant continues his or her infringing activity, remedies will be available in respect of the continued activity. Where infringement began more than six years prior to an action and continued, remedies are available for all infringement that occurred more recently than six years prior to the action.

Patent Act, supra note 11, s 54.

See supra note 55 and accompanying text for a definition of infringement. Patent Act, supra note 11, s 57(1).

Ibid, s 55(1).

Ibid, s 55(2). See Jay-Lor International v Penta Farm Systems Ltd, 2007 FC 358, 59 CPR (4th) 228 at para 122, where "reasonable compensation" was held to be equivalent to a "reasonable royalty."

Federal Courts Act, RSC 1985, c F-7, s 20(2). A successful claimant for patent infringement is not necessarily entitled to equitable relief. If the court allows an award of equitable relief, the successful claimant must elect either damages or equitable relief.

Ibid. See e.g. Apotex v Bristol-Myers Squibb Co, 2003 FCA 263, 26 CPR (4th) 129 [Bristol-Myers Squibb].

Bristol-Myers Squibb, ibid.

Federal Court Rules, SOR/98-106, s 220. This is often done by a consent order.

Patent Act, supra note 11, s 55.01. 
Once issued, a patent is presumed to be valid. ${ }^{113}$ However, a defendant in an action for patent infringement may include in his or her defence allegations that the patent is void and bring a counterclaim to impeach the patent or any claim of the patent. ${ }^{114}$ The defendant in an action for patent infringement will typically commence a counterclaim. Where some claims of a patent are found invalid, the patent will be considered to include only the claims not found invalid. An impeachment action may also be commenced in the absence of a claim for infringement. ${ }^{115}$

\section{B. CONSTRUCTION}

Prior to assessment of whether a claim is infringed or invalid, the claim must be construed. ${ }^{116}$ The same construction is applied for determining both infringement and validity of the claim. ${ }^{117}$ The claim is construed in the context of the specification as a whole, ${ }^{118}$ including other claims ${ }^{119}$ and the description, ${ }^{120}$ as of the publication date of the application for the patent. ${ }^{121}$ Exchanges between CIPO and the applicant during prosecution of the patent and other documents outside the specification are not relevant to the construction of the claims. $^{122}$

The same claim construction is to be used for all infringement litigation purposes. The construction is notionally made independently of any allegations of infringement or validity made in respect of the claim. ${ }^{123}$ However, in the interest of practicality, the court has recognized that it "is not to construe a claim without knowing where disputes between the parties lie." "124

Claims are construed purposively by the court. Purposive construction means determining the scope of the monopoly of a claim as understood by the person to whom the patent is directed (see below) and based on his or her reading of the whole specification. The Supreme

Ibid, s 43(2).

Ibid, ss 59, 60(1). A successful impeachment action results in a patent, or one or more claims of the patent, becoming void and unenforceable.

Ibid, s 58.

Whirlpool Corp v Camco, 2000 SCC 67, [2000] 2 SCR 1067 at para 43 [Whirlpool].

Ibid at paras 49(a)-(b).

Ibid at paras 48, 52. As discussed above, supra notes 13-17 and accompanying text, the specification of a patent includes the claims, description, and figures, but not the abstract.

Eli Lilly and Company v Apotex, 2009 FC 991, 80 CPR (4th) 1 at paras 89-90 [Cefaclor (TD)], aff'd 2010 FCA 240, 90 CPR (4th) 327. The shorthand of this case refers to a compound whose manufacturing processes allegedly infringed on one or more claims in a group of patents held by Eli Lilly \& Co. A similar shorthand is used for Apotex $v$ Wellcome Foundation Ltd, 2002 SCC 77, [2002] 4 SCR 153 [AZT]; Eli Lilly Canada v Novopharm Ltd, 2010 FCA 197, 85 CPR (4th) 413 [Olanzapine (CA)].

Whirlpool, supra note 116 at para 52. See also Janssen-Ortho v Canada (Minister of Health), 2010 FC 42, 361 FTR 268 at para 119.

Whirlpool, ibid at para 55; Free World Trust v Électro Santé, 2000 SCC 66, [2000] 2 SCR 1024 at paras 52-54 [Free World Trust].

Free World Trust, ibid at paras 61-67. These documents are typically argumentative correspondence between the applicant and CIPO, a process called "prosecution," during which the scope of the claims often changes. To allow documents other than the specification itself to be considered for determining the scope of the monopoly granted by the claims would undermine the role of the patent in making it clear to the public what is, and what is not, subject to the monopoly granted to the patentee (see ibid at para 41 for further description of the public notice purpose of a patent). This could lead to a similar problem as that caused by ambiguous claims (see discussion below at notes 137-38).

Whirlpool, supra note 116 at para 49(a).

Cefaclor (TD), supra note 119 at para 88, citing Shire Biochem v Canada (Minister of Health), 2008 FC 538, 328 FTR 123 at para 21. 
Court of Canada has distinguished purposive construction from "the kind of meticulous verbal analysis in which lawyers are too often tempted by their training to indulge."125 Purposive construction is made with "a mind willing to understand, not by a mind desirous of misunderstanding." ${ }^{126}$ Purposive construction may result in the expansion or limitation of the literal meaning of the claim. ${ }^{127}$ While reference to the rest of the specification may assist the court in understanding what was meant by the terms in a claim, the scope of the claim as written (as opposed to its literal meaning) may not be enlarged or contracted by reference to the rest of the specification. ${ }^{128}$ Purposive construction also includes dividing a claim into essential and non-essential elements. A defendant in an infringement action is liable for patent infringement if he or she is practicing all essential elements of the claim. Variation or omission of non-essential elements will still result in a finding of infringement where all essential elements of the claim are practiced. ${ }^{129}$ Elements of a claim are presumed to be essential, unless it is proven that they are not essential. ${ }^{130}$

Patents are not directed to the public generally but to a person ordinarily skilled in the art (POSITA) to which the patent pertains. Purposive construction is from the perspective of the POSITA. The definition of a POSITA, including his or her level of education and experience, is contextual: “'Ordinariness' will, of course, vary with the subject matter of the patent. Rocket science patents may only be comprehensible to rocket scientists." ${ }^{131}$ In one case, the Federal Court found that the relevant POSITA, while lacking much formal education, would have an understanding of how mechanical devices function and are constructed and used, including "how oil and gas wells are drilled, including the various drilling environments." 132

The POSITA will understand the claim in view of his or her common general knowledge (CGK) as of the date of publication of the application within which the claim is found. ${ }^{133}$ The Supreme Court of Canada has given a plain meaning definition to CGK: "Common general knowledge means knowledge generally known by persons skilled in the relevant art at the relevant time." ${ }^{134}$ As the specification of a patent is directed to the POSITA, determining who the POSITA is and the content of his or her CGK precedes construction of a claim and is required where infringement and/or validity of a claim are in issue. The identity of the POSITA and the content of his or her CGK are each typically supported by expert evidence.

Whirlpool, supra note 116 at para 48, citing Catnic Components Ltd v Hill \& Smith Ltd, [1982] RPC 183 at 243 (HL).

Whirlpool, ibid at para 49(c), citing Lister v Norton Brothers and Co, [1886] 3 RPC 199 (Ch D) at 203. See also Burton Parsons Chemicals v Hewlett-Packard (Canada) Ltd, [1976] 1 SCR 555 at 563. Whirlpool, ibid at para 49(h).

Ibid at para 52.

Ibid at paras 44-48.

Free World Trust, supra note 121 at para 55 [emphasis in original]:

For an element to be considered non-essential and thus substitutable, it must be shown either (i) that on a purposive construction of the words of the claim it was clearly not intended to be essential, or (ii) that at the date of publication of the patent, the skilled addressees would have appreciated that a particular element could be substituted without affecting the working of the invention, i.e., had the skilled worker at that time been told of both the element specified in the claim and the variant and "asked whether the variant would obviously work in the same way", the answer would be yes.

Whirlpool, supra note 116 at para 71.

Wenzel Downhole Tools Ltd v National-Oilwell Canada Ltd, 2011 FC 1323, 98 CPR (4th) 155 at para 46 [Wenzel]. An appeal of this matter was heard on 10 October 2012 in Edmonton before Justice Nadon, Justice Gonthier, and Justice Mainville. Judgment was reserved.

Free World Trust, supra note 121 at para 44.

Apotex v Sanofi-Synthelabo Canada, 2008 SCC 61, [2008] 3 SCR 265 at para 37 [Sanofi]. 


\section{VALIDITY}

As discussed above, the Patent Act requires that the subject matter of a claim be novel and inventive. ${ }^{135}$ It can sometimes be intuitive to lump these requirements into one, as they each involve a comparison between the scope of a claim and the prior art. However, these two requirements are different. The case law provides a simple and useful distinction between the requirements for novelty (in other words, that the subject matter of the claim is not anticipated by the prior art) on the one hand, and for inventiveness (in other words, that the subject matter of the claim is not obvious to a POSITA):

They are, of course, quite different: obviousness is an attack on a patent based on its lack of inventiveness. The attacker says, in effect, “Any fool could have done that.” Anticipation, or lack of novelty, on the other hand, in effect assumes that there has been an invention but asserts that it has been disclosed to the public prior to the application for the patent. The charge is: "Your invention, though clever, was already known.”136

The subject matter of a claim must also have utility or a sound prediction of utility. ${ }^{137}$ Other requirements for patent claims and specifications include that the description be sufficient ${ }^{138}$ and that the claims lack ambiguity. ${ }^{139}$ The below discussion is limited to tests for novelty, inventiveness, and utility (including sound prediction of utility).

\section{VALIDITY - NOVELTY}

While the requirement for novelty is based in the Patent Act, the test for novelty is defined by case law. In order to anticipate a claim, a single document or other disclosure (for example, the sale of a product or application of a method) made available to the public in accordance with the timing requirements of section 28.2 of the Patent Act ${ }^{140}$ must both "disclose" and "enable" the subject matter of the claim. Where a single document or other disclosure discloses and enables the subject matter of a claim, it anticipates the claim and the

Supra note 11, ss 28.2(1), 28.3. See supra notes 44-46.

Beloit Canada Ltd v Valmet Oy (1986), 8 CPR (3d) 289 at 293 (FCA); leave to appeal to SCC refused, [1986] 1 SCR xv.

Utility is required by section 2 of the Patent Act, supra note 11 . Sound prediction of utility is described in AZT, supra note 119 at para 70.

Patent Act, ibid, s 27(3). See Consolboard, supra note 16 at 517, where the Supreme Court of Canada ruled that "[t]he description of the invention therein provided for is the quid pro quo for which the inventor is given a monopoly for a limited term of years on the invention." At 520, the Court described the requirement for sufficiency of description as being correct and full answers to two questions: "What is your invention? How does it work?" The correct and full answers to each question must enable the public to "make the same successful use of the invention as the inventor could at the time of his application" using only the specification (citing Noranda Mines Ltd v Minerals Separation North American Corp (1947), 12 CPR 99 at 102). Put otherwise, the description "must define the nature of the invention and describe how it is put into operation" (Pioneer Hi-Bred Ltd v Canada (Commissioner of Patents), [1989] 1 SCR 1623 at 1638. See also Pfizer Canada v Novopharm Ltd, 2010 FCA 242, [2012] 2 FCR 69, leave to appeal granted, 33951 (23 November 2010) (appeal heard and reserved on 18 April 2012)).

Patent Act, ibid, s 27(4). In Apotex v Hoffman-La Roche Ltd (1989), 24 CPR (3d) 289 at 299 (FCA), a claim was found to be capable of two interpretations and was thus ambiguous and invalid. However, where a claim can be properly interpreted using grammatical rules and common sense, it is not ambiguous (Mobil Oil Corp v Hercules Canada (1995), 63 CPR (3d) 473 at 484 (FCA) [Mobil Oil (CA)], leave to appeal to SCC refused, 25012 (27 November 1995). In Pfizer Canada v Canada (Minister of Health), 2005 FC 1725, 46 CPR (4th) 244, var'd on other grounds, 2007 FCA 1, 54 CPR (4th) 353, the Court reviewed Mobil Oil (CA) and other authorities and held at para 53 that, "[i]n short, ambiguity is truly a last resort, rarely, if ever, to be used.”

As discussed above, supra notes 44-46. See Patent Act, ibid, ss 28.2(1), 28.3. 
claim lacks novelty. To support a finding that the publication discloses the claimed invention, it must disclose the special advantage of the claim to the POSITA, without requiring the POSITA to undertake any trial and error. In contrast, when assessing whether a publication enables a POSITA to practise the invention without undue burden, his or her CGK applies and routine experimentation is acceptable and would not be considered an undue burden. ${ }^{141}$ Any public document, including published patent applications, issued patents, and peerreviewed journals, may be anticipatory.

Sale of a product, public use of a product, or public practice of a method may constitute making subject matter available to the public where the event discloses and enables the subject matter of the claim. ${ }^{142}$ For example, unconditional sale of a $\mathrm{H}_{2} \mathrm{~S}$ scavenging solution was found to be an anticipatory disclosure where reverse-engineering of the solution using techniques available at the relevant time would have led the POSITA to the claimed invention. ${ }^{143}$ In another example, rental of a bearing assembly for a drill bit, which was used on a job prior to the claim date, anticipated claims of the patent. While the bearing assembly was not actually dismantled and inspected, drawings of the assembly were available for inspection. The bearing assembly could have been dismantled, and if it had become stuck in the well, the drawings would have been provided to a fisherman to assist in retrieval of the assembly. The assembly had been tested prior to the job it was used on and the job was commercial as opposed to experimental (see below). ${ }^{144}$

Where a disclosure is subject to a duty of confidence, the subject matter disclosed is not “made available to the public.” In accordance with LAC Minerals, a duty of confidentiality may be present, notwithstanding the lack of a written NDA. The test is whether "any reasonable man standing in the shoes of the recipient of the information would have realised that upon reasonable grounds the information was being given to him in confidence." 145 For example, sale of a sealing assembly for a rotating stuffing box and presentations that disclosed the inner workings of the assembly were held to be not anticipatory because the sale and presentations were subject to a duty of confidentiality. ${ }^{146}$ The entities respectively providing and receiving the information shared a common cause of eliminating leakage from stuffing boxes and had a relationship of trust and cooperation which resulted in a reasonable expectation of confidence. Rig crews, flush-by crews, service crews, and casual observers

Sanofi, supra note 134 at paras 28-37.

Disclosure by use or sale of the applicant (or a person who obtained knowledge of the invention from the applicant) must also be more than one year prior to the filing date. See e.g. 671905 Alberta v Q'Max Solutions, 2001 FCT 888, 14 CPR (4th) 129 [Q'Max (TD)], var'd by 2003 FCA 241, 27 CPR (4th) 385 [Q'Max (CA)], leave to appeal to SCC refused, 29926 (2 September 2003). In Q'Max (TD), field testing of a drilling mud occurred within one year prior to the date of filing and was not citable against the claim (at para 60). Anticipation by use was not at issue in Q'Max (CA) (at paras 43-54).

143 Baker Petrolite Corp v Canwell-Enviro Industries Ltd, 2002 FCA 158, 211 DLR (4th) 696 at paras 42 , 98-99 [Baker]. Baker predated Sanofi, supra note 134, and applied a different test for anticipation. However, at para 86 of Wenzel, supra note 132, Justice Snider recognized that Baker predated Sanofi and nonetheless applied relevant aspects of the law on anticipation by public disclosure, noting that some portions of para 42 of Baker presaged Sanofi. In addition, Baker was distinguished on the facts (as opposed to being based on an outdated and incorrect statement of the law of anticipation) in Weatherford Canada Ltd v Corlac Inc, 2011 FCA 228, 95 CPR (4th) 101 at paras 36-65 [Weatherford (CA)], var'g 2010 FC 602, 84 CPR (4th) 237 [Weatherford (TD)], leave to appeal to SCC refused, 34459 (29 March 2012).

144 Wenzel, supra note 132 at paras 96-146, and particularly at paras 104, 113, 116, 119-124, 137-39.

145 Weatherford (CA), supra note 143 at para 48. See also Weatherford (TD), supra note 143 at paras $298-$ 99,315 . These portions of the reasons of Weatherford (CA) and Weatherford (TD) rely on LAC Minerals, supra note 25 at paras 635-36, citing Coco, supra note 25 at 47. 
were able to observe installation of the sealing assemblies. However, these individuals were able to observe assembled units only and would not have been able to observe internal workings of the sealing assembly — this was not sufficient to disclose the claimed subject matter. While the individuals working in the field did not generally believe there to be a duty of confidentiality, those higher up on the corporate ladder did perceive such a duty. ${ }^{147}$

Where activities (such as sale or use) that disclose and enable the subject matter of a claim are experimental, the activities are not anticipatory. ${ }^{148}$ Similarly, where a unit is a "test unit," practice in the oil and gas industry supports a finding that disclosure related to the unit is subject to a duty of confidentiality. ${ }^{149}$ Either a duty of confidence or experimental use (which is supported by a duty of confidence, although such a duty is not necessarily required to support a finding of experimental use) will suffice to prevent a disclosure from being "to the public.” Thus, the practical difference between "experimental use” (one indicator of which is a duty of confidentiality) and use of "test units," resulting in a duty of confidentiality because of industry practice, is obfuscated by the case law. ${ }^{150}$ In any event, where it is necessary to practice an invention on a job site to further its development prior to filing a patent application disclosing the method or tool, steps should be taken to ensure that all personnel present either sign NDAs or are at least verbally informed that testing is occurring and they are subject to a duty of confidence. To the extent possible, the new technology being applied should be concealed from those who do not need to understand its details. Any documents that must be present on the job site relating to the new technology should be labeled as confidential and clearly labeled as the property of the innovator. In addition, the experimental nature of the event should be documented to support a later finding of experimental use. Briefly, where subject matter must be practised prior to filing a patent application, efforts should be directed to documenting facts that may potentially serve as evidence to support each of these exceptions to disclosure to the public. To provide greater certainty that either a duty of confidence will apply to those witnessing the use or that the use is experimental, counsel should be involved as far in advance of the use as possible.

\section{E. VALIDITY - INVENTIVENESS}

As with novelty, the requirement for inventiveness is based in the Patent Act, while the test is defined by case law. In order to determine whether the subject matter of a claim lacks inventiveness (in other words, whether the subject matter is obvious), the POSITA, his or her CGK, and the inventive concept of the claim must each be identified. The differences, if any, that exist between the CGK and the inventive concept are then defined and a determination

Weatherford (CA), ibid at paras 36-65, and particularly at paras 36-38, 48-53; Weatherford (TD), ibid at paras 283-322, and particularly at paras 293, 297, 300-307, 311, 316.

Wenzel, supra note 132 at para 139, citing Gibney v Ford Motor Co of Canada (1967), 52 CPR 140 at 158-64. The use in Wenzel was found to be experimental because there was no confidentiality obligation, there was no report of any problems or other feedback provided following the use, and the inventor did not remain at the location long enough to see the bearing assembly used (at para 142). Prior to Wenzel, there was a recognized uncertainty as to whether the experimental use exception to disclosure to the public was still good law (see Fraser D Rowand, “Anticipating Your Own Invention: A Comparative Analysis of Self-Triggered Patent-Barring Events in Canada, Europe, and the United States” (2003) 20 CIPR 135). Subject to an appeal or overruling of Wenzel, it appears that the experimental use exception to disclosure to the public remains good law.

Weatherford (CA), supra note 143 at paras 38-39, 61, 65.

Wenzel, supra note 132 ("testing" and "experimental" are each referred to in para 142); Weatherford (CA), ibid ("industry practice" is relied upon to establish a duty of confidentiality). 
is made of whether those differences would have been either inventive or obvious. ${ }^{151}$ If the differences are obvious, then the claim is invalid for claiming obvious subject matter. If the differences are inventive, then the claim is not invalid on this basis. When determining whether the differences are inventive or obvious, the courts will consider whether it would have been "obvious to try" a given solution, which may apply in fields where advancement is won by experimentation. ${ }^{152}$

Unlike novelty, which is determined with respect to a given document or disclosure, inventiveness is assessed with respect to the relevant CGK. Specific documents, including patents or published applications, may be part of the CGK. Whether a given document is within the CGK is a factual question. Since the CGK will invariably include multiple documents and inventiveness is determined with respect to the CGK, the collective effect of multiple documents on the validity of a claim may be considered. ${ }^{153}$ For example, where the POSITA would understand a patent for a bearing assembly in a drill, an edition of the World Oil Composite Catalog was found to be within the CGK, but patents from outside of the field of downhole oilfield applications were not part of the CGK. ${ }^{154}$

Written publications must be retrievable in a reasonably diligent search by the POSITA to be citable in an inventiveness analysis. ${ }^{155}$ This distinction between anticipation and obviousness is particularly relevant to public disclosures other than publication in patent applications or peer-reviewed articles and public disclosures by sale or otherwise than in a written or illustrated publication. ${ }^{156}$ The courts have recognized that the date as of which the POSITA construes a claim is relevant to assessing the content of CGK in that the POSITA's ability to retrieve information in a reasonably diligent search is determined in part by the available technology to perform the search. For example, where the CGK is assessed as of the mid 1980s, the CGK may be limited to research conducted with the technology of the time, such as libraries with index cards. In the mid 1980s, there was no Internet providing information in an instantaneous and electronic fashion. As a result, the CGK of a POSITA would not necessarily include all information available on Internet search tools that have since become available. ${ }^{157}$

Sanofi, supra note 134 at paras 62-69. Construing the claim is presented as an alternative to defining the inventive concept of the claim.

Ibid at paras 68-69. Factors that favour a finding that a solution is obvious to try include: the number of identified predictable solutions being relatively low; a lower extent of required experimentation; the experimentation being routine; and a motive provided in the prior art to pursue the solution. "Obvious to try" is not synonymous with "worth a try” (Ratiopharm v Pfizer Ltd, 2009 FC 711, 76 CPR (4th) 241 at paras 163-66 [Ratiopharm (TD)], aff'd 2010 FCA 204, 87 CPR (4th) 185 at para 15 [Ratiopharm (CA)]).

See Cefaclor (TD), supra note 119 at paras 412-27.

Wenzel, supra note 132 at paras 152-73. Two patents that were excluded related to a railway car (at para 168) and a device used in electric motors (at para 170). Two other patents were excluded from the CGK because they were published in Japanese and German (at para 166). The POSITA in Wenzel dated to 1990 and had an understanding of many mechanical devices, how oil and gas wells are drilled, and experience with tools (at para 151).

Ibid at para 172. See also Apotex v Sanofi-Aventis, 2011 FC 1486, [2011] FCJ no 1813 (QL) at paras 602-603 [Sanofi 2011]. See also Janssen-Ortho v Novopharm, 2006 FC 1234, 57 CPR (4th) 6 at para 57 [Janssen-Ortho], aff'd by 2007 FCA 217, 59 CPR (4th) 116.

See e.g. Sanofi 2011, ibid at paras 615-28, where posters and abstracts displayed at conferences in 1985 and 1986 were not part of the CGK as of 1987 . However, a peer-reviewed publication in the European Journal of Pharmacology was part of the CGK (ibid at paras 639-44). See also Janssen-Ortho, ibid at para 57, where a poster that was displayed for three hours at a conference in 1982 but was not published by way of distribution would not have been found in a reasonably diligent search by a POSITA in 1985. Sanofi 2011, ibid at para 624. 
Public uses other than in written or illustrated media may also be citable for obviousness. For example, in Weatherford (CA), allegations that a sale made the subject matter of a claim obvious were unsuccessful because the sale did not constitute disclosure of information such that it was "available to the public." 158

\section{F. VAlidity - Sound PREdiction of Utility, Demonstration of Utility, AND Promise of The Patent}

The subject matter of a claim must have utility. ${ }^{159}$ This can be either demonstrated or soundly predicted as of the filing date of the patent application. To soundly predict the subject matter of a claim, the specification must include a prediction, a factual basis for the prediction, and a sound line of reasoning from the factual basis to the prediction. Each element of sound prediction must be disclosed in the specification. ${ }^{160}$

"[T] he promise of a patent is an aspect of claims construction"161 and "is fundamental to the utility analysis." 162 The promise of a patent is construed in the context of the patent as a whole, from the perspective of the POSITA, as of the filing date. ${ }^{163}$ "Where the specification does not promise a specific result, no particular level of utility is required; a 'mere scintilla' of utility will suffice. However, where the specification sets out an explicit 'promise', utility will be measured against that promise." 164 Thus, the onus of establishing that a patent includes a promise with respect to one or more claims appears to lie with the party alleging invalidity of the claim(s). Where a promise is made, it must be met in the claimed embodiments, otherwise the claim is invalid for lack of demonstrated utility, for lack of sound prediction of utility, or for overbreadth. ${ }^{165}$ Where a defendant in a patent infringement suit fails to clearly define the promise of a patent, he or she will be unable to establish that the patent at issue lacks utility. In one case, expert evidence that a patented bearing design in a drill bit would wear out quickly failed to convince the court either that a promise had been made or that a promise had not been met. The experts who provided testimony did not comment on the promise of the patent until prompted during oral testimony. When prompted, they did not provide a comprehensible response. The specification of the relevant patent did not include a promise of any particular durability. ${ }^{166}$

Weatherford (TD), supra note 143 at paras 319-22.

Patent Act, supra note 11, s 2.

$A Z T$, supra note 119 at para 70 . The sound prediction was characterized in $A Z T$ as "to some extent the quid pro quo the applicant offers in exchange for the patent monopoly" (ibid). There is no citation, but this uses the same language as Consolboard, supra note 16.

Laboratoires Servier v Apotex, 2009 FCA 222, 75 CPR (4th) 443 at para 101.

Olanzapine (CA), supra note 119 at para 93.

Ibid.

Ibid at para 76.

Eurocopter v Bell Helicopter Textron Canada Ltée, 2012 FC 113, 100 CPR (4th) 87 at paras 333, 36971, 386 [Eurocopter]. More specifically, the decision also found that as a result of the claims' failure to meet their respective promises, the claims are invalid for "lack of demonstrated utility (or sound prediction) and/or overbreadth" (ibid at para 371). Briefly, where the subject matter of a claim is beyond what was invented, the claim is overbroad. An overbroad claim provides the patent holder with the exclusive right to exploit subject matter not invented and not disclosed to the public, which makes unfair the bargain discussed above (see supra note 16). See also Hershkovitz v Tyco Safety Products Canada Ltd, 2010 FCA 190, 89 CPR (4th) 101 at para 16.

Wenzel, supra note 132 at paras 211-12. 


\section{G. VALIDITY - SECTION 53(1)}

Some jurisdictions outside of Canada have statutory provisions in their patent legislation directed to issues of fraud. Section 53(1) of the Patent Act has been likened to such provisions. ${ }^{167}$ That section states:

A patent is void if any material allegation in the petition of the applicant in respect of the patent is untrue, or if the specification and drawings contain more or less than is necessary for obtaining the end for which they purport to be made, and the omission or addition is willfully made for the purpose of misleading. ${ }^{168}$

In order to be "material," an allegation must relate to the subject matter of the claims in the patent as granted. While section 53(1) of the Patent Act specifies that an untrue material allegation must be present in the petition of the applicant, section 53(1) has been ruled to apply to such allegations present in the specification. ${ }^{169}$ Section 53(1) does not apply to untrue allegations made to CIPO during prosecution of a patent application outside of the petition or specification. For example, it would not apply to the failure to disclose relevant prior art. $^{170}$

Decisions addressing section 53(1) allegations unrelated to inventorship have variously found that wilfulness must only be proven in respect of omissions or additions, ${ }^{171}$ or that it must also be proven in respect of untrue material allegations. ${ }^{172}$ Section 53(1) has been argued as a basis upon which to invalidate patents where inventors were named in the petition who were not, in fact, inventors and where alleged inventors were not named. To void a patent for an untrue allegation relating to inventorship, the allegation must be found to have been both material and made for the purposes of misleading. ${ }^{173}$ Whether an allegation

Ratiopharm (TD), supra note 152 at para 195.

Supra note 11, s 53(1).

Rothmans, Benson \& Hedges v Imperial Tobacco Ltd (1991), 35 CPR (3d) 417 (FCTD) at 429 [Rothmans], aff'd without treatment of this point (1993), 47 CPR (3d) 188 (FCA).

Weatherford (CA), supra note 143 at paras 149-50. The Federal Court of Appeal made it clear that section 73(1)(a) of the Patent Act, supra note 11, is not a legislative basis under which to impose a duty of candour during prosecution, overruling two previous decisions of the Federal Court Trial Division (Weatherford (CA), ibid at para 151). See also Eli Lilly and Co v Apotex (1998), 80 CPR (3d) 80 (FCTD) at paras 25-27, aff'd on other grounds, (2000), 8 CPR (4th) 52 (FCA).

Mobil Oil Corp v Hercules Canada (1994), 57 CPR (3d) 488 (FCTD) at 508 [Mobil Oil (TD)]. Mobil Oil (TD) was reversed without discussion on this point by Mobil Oil (CA), supra note 139. See also Zambon Group SPA v Teva Pharmaceutical Industries Ltd, 2005 FC 1585, 44 CPR (4th) 173 at paras 2-3, 5, 31.

Bauer Hockey Corp v Easton Sports Canada , 2010 FC 361, 83 CPR (4th) 315 at paras 323-33 [Bauer], aff'd without treatment of section 53(1) by 2011 FCA 83, 92 CPR (4th) 103. See also Eurocopter, supra note 165 at para 68. These decisions post-date AZT, supra note 119 (see discussion below, at note 173) and apply the requirements of section 53(1) of the Patent Act broadly in that they described the requirement for intention to mislead as applying outside of inclusion of untrue material allegations relating to inventorship. However, neither decision is conclusive on whether this is the correct application of AZT. In Bauer, the party alleging invalidity further failed to prove that the allegations were either untrue (at para 332) or material (at para 333). In Eurocopter, section 53(1) was not pled and was only referred to during an explanation of overbreadth of claims (at para 70). See supra note 165 for a brief definition of overbreadth.

AZT, supra note 119 at para 94. See also Q'Max (CA), supra note 142 at para 31. 
is material is fact-specific, ${ }^{174}$ and intention to mislead can be inferred. ${ }^{175}$ The court has more than once referred to invalidation of a patent for failing to accurately name the inventors as “a draconian remedy," and it appears reluctant to invalidate a patent on this basis. ${ }^{176}$ Nonetheless, it is advisable to ensure that all the correct inventors, and only correct inventors, are named in respect of all patent applications. This is a simple way to reduce uncertainty and eliminate a potential ground for allegations of invalidity.

An inventor is anyone who contributed to an inventive concept and reduced it to a definite and practical shape. An individual involved merely in verification of an invention once it has already been reduced to practice is not an inventor. ${ }^{177}$ Reducing the invention to a definite and practical shape means doing more than conceiving of general ideas or a thesis; the general idea or thesis must be built as described or fully described. This analysis is applied to the combination of elements necessary to practice the invention, and not to the individual elements. $^{178}$

\section{Conclusion}

The Alberta oil sands are a vast resource that will be increasingly exploited as homegrown technology makes such exploitation more financially and environmentally effective. In order to increase company value and preserve competitive advantage, considerable thought should be given to how to best protect innovative technology. By protecting technology through patents and trade secrets, a company with operations in the Alberta oil sands will benefit from the generation of assets, the preservation of competitive advantages, and a general increase in the value of its business.

Weatherford (CA), supra note 143 at paras 126-29. The appellants failed to demonstrate that inventorship was material, or that "any particular combination of facts will necessarily render the identity of an inventor material for the purpose of subsection 53(1)" (at para 129). See also Q'Max (CA), ibid at paras 29, 32, where the appellants failed to demonstrate that there was either wilful intention to mislead or that misnaming an inventor was material to the public.

Ratiopharm (TD), supra note 152 at para 203. The ruling on s 53(1) in Ratiopharm (CA), supra note 152 at para 34 limits the application of the portions of Ratiopharm (TD) addressing s 53(1): "Pfizer expressed concern that the trial judge's determination pursuant to subsection 53(1) of the Act was based on an overly broad interpretation of that subsection. I am of the view that the determination is confined to the unique and particular circumstances of this matter. It has limited, if any, value as a precedent.” However, it is unclear whether this means that the general statement that intention to mislead can be inferred is not good law. Further, in Bauer, supra note 172 at para 335, this application of s 53(1) was cited favourably. AZT, supra note 119 at paras $97-99$.

178 Weatherford (TD), supra note 143 at paras 235-241, aff'd on this point specifically, Weatherford (CA), supra note 143 at para 99. 